\title{
Zika-vírus-fertőzés terhességben
}

\author{
Varjasi Gabriella dr. ${ }^{1}$ - Póka Róbert dr. ${ }^{2}$ \\ ${ }^{1}$ Szabolcs-Szatmár-Bereg Megyei Jósa András Oktatókórház, Szülészet-Nőgyógyászat Osztály, Nyíregyháza \\ ${ }^{2}$ Debreceni Egyetem, Általános Orvostudományi Kar, Klinikai Központ, Szülészeti és Nőgyógyászati Intézet, \\ Debrecen
}

\begin{abstract}
A Zika-vírus az Aedes aegypti és Aedes albopictus szúnyogok által terjesztett Flavivírus. 2015-tól robbanásszerúen terjedt el Dél-Amerikában, és 2016-ban már Észak-Amerikában, illetve Európában is jelentettek eseteket. A legtöbb fertőződés tünetmentesen zajlik, azonban várandós nők magzatában microcephaliát okozhat. A vírusfertőzés a Guillain-Barré-szindróma növekvő előfordulásában is szerepet játszhat. Az akut, autoimmun demyelinisatiós betegség súlyos esetben halálhoz is vezethet. Bár specifikus antivirális terápia, 2016 júliusától már DNS-alapú vakcinák hatásosságát vizsgálják emberben. A világ lakosságának több mint a fele él fertôző szúnyogok által elárasztott területen, és a vektorkontroll-stratégiák egyelőre nem elég hatásosak a járvány visszaszorítására. A szúnyogcsípés elleni védekezés leginkább fertilis korú nők és várandósok esetében fontos, fóleg, ha járvány sújtotta területre utaznak. Legbiztonságosabb megoldás a gyermekvállalás és az utazás elhalasztása addig, amíg a járvány le nem csillapodik. A globális éghajlati változásoknak köszönhetően hazánkban is rábukkantak már Aedes albopictus fajokra, amelyek a kontinensen lassan, de folyamatosan terjednek, viszont ezek megtelepedéséról még nem rendelkezünk információval. Magyarországon behurcolt esetekkel találkozhatunk, és egyelőre nem kell a járvány hazai kialakulásától tartani. A szomszédos országokban, például Szlovéniában és Szlovákiában, már jelentettek fertőzéses eseteket. A Zika-vírus jövője egyelőre kiszámíthatatlan, de a Dengue- és a Chikungunya-vírus világméretű terjedését tekintve, a Zika-vírus valószínúleg a nyomdokaikba lép a közeljövőben. Orv. Hetil., 2017, 158(15), 563-571.
\end{abstract}

Kulcsszavak: Zika-vírus, terhesség, microcephalia

\section{Zika virus infection in pregnancy}

The Zika virus is a flavivirus spread by mosquitoes. Its primary vectors are the Aedes aegypti and the Aedes albopictus. Before 2007 it sporadically caused benign morbidity. Since 2015, it started spreading "explosively" in America, especially in Brazil. In August 2016 they reported cases from New York and Poland, too. Most of the infections don't produce any symptoms, but can cause grave complications. The most important lesion is microcephalia that forms in fetuses. Microcephalia's most serious consequence is mental retardation, which puts great burden on both the family and the society. The viral infection increases the incidence of Guillain-Barré syndrome. This is an acute autoimmune disease which causes demyelination and, in the worst cases, it can also be fatal. Yet we do not possess adequate and specific vaccination nor antiviral therapy, although, since July 2016, the effectiveness of a DNA based vaccine is being tested on humans. More than half of the world's population lives in areas contaminated by infected mosquitoes so there is a great need for the development of an effective method against the vector mosquitoes. Sadly, even the vector control strategies aren't effective enough to push back the epidemic. Pregnant or fertile women must take the highest precautions against mosquito bites, especially if they travel to regions ravaged by the epidemic. The safest solution would be to postpone both the trip and the childbearing. In Europe, the vectors aren't spread enough to cause major threat, except maybe the warmer regions bordered by the Mediterranean Sea. However, it is possible that in the near future other viruses spread by Aedes mosquitoes could appear. Naturally, the travellers and immigrants, who came from endemic regions can also contribute to the spread of the epidemic. Thanks to the changes in global weather, there were reported findings of mosquitoes of the Aedes albopictus species in Hungary, which are slowly invading the continent, although we do not have information about their settlement in the country. The doctors may encounter introduced cases and we do not have to fear the spreading of the epidemic to our country, but in the bordering Slovakia and Slovenia infections have been reported. The future of the Zika virus is yet unpredictable, although looking at the global spread of the Dengue and Chikungunya viruses, a worldwide spread is expectable in the near future.

Keywords: Zika virus, pregnancy, microcephalia

Varjasi, G., Póka, R. [Zika virus infection in pregnancy]. Orv. Hetil., 2017, 158(15), 563-571.

Az Orvosi Hetilap alapításának 160. évében a Szerkesztőség felkérésére készített tanulmány.

(Beérkezett: 2017. február 10.; elfogadva: 2017. március 1.) 


\section{Rövidítések}

$\mathrm{AXL}=$ tirozinkináz-receptor; $\mathrm{CMV}=$ cytomegalovirus; $\mathrm{DNS}=$ deoxiribonukleinsav; ECDC = Európai Betegségmegelőzési Központ; EMG = elektromiográfia; RIDL = domináns letalis gént hordozó rovar kibocsátása; RNS = ribonukleinsav; PRNT = plakkredukció-neutralizációs teszt

Napjainkban az orvostudomány egyik legfontosabb és legaktuálisabb témája a Zika-vírus-fertőzés - a szülészetnőgyógyászat területén is. Jelentőségét a számos kontinensen való elterjedés és a súlyos neurológiai, szemészeti és szülészeti szövődmények adják. Az egészségügyben dolgozók számára igen nagy kihívást jelent a járvány megfékezése, a fertőzés felismerése, a megfelelő diagnosztikus és prevenciós eljárások kidolgozása, valamint a vakcina kifejlesztése.

Először 1947 áprilisában izolálták egy lázas rhesus majom szérumából. Nevét a kelet-afrikai, Ugandában elhelyezkedő víruskutató intézet mellett elterülő Zika erdőről kapta. A Zika a lugandai nyelvben elburjánzottat, hirtelen nöttet jelent.

1948-ban Aedes africanusból izolálták. Az első humán megbetegedést 1952-ben jelentették [1]. Évtizedeken át, egészen 2007-ig többnyire csak majmokat érintett a fertőzés, és ritkán, elszórtan okozott benignus emberi infekciókat Ázsia és Afrika területén [2]. 2007-ben a Mikronéziai Szövetségi Államokban terjedt el, 2015-ben Amerika területén is megjelent, később pedig már 28 ország területéről jelentettek vírusfertőzéseket. Ezekből az időpontokból is tisztán kitûnik, hogy a vírus váratlanul, robbanásszerúen terjedt el rövid idő alatt számos területen.

Sajnos nemcsak a gyors elterjedés jelenti a problémát, hanem az is, hogy a korábbi tapasztalatokhoz képest sokkal súlyosabb megbetegedések kialakulásához vezet a fertőződés. Ilyen például a myelitis, meningoencephalitis és a Guillain-Barré-szindróma, amely később halálhoz vezethet.

Ezenkívül nagy hangsúlyt kell fektetni a terhes anyák vírusfertőzésére is, mivel ez maradandó és súlyos károsodásokat okozhat a magzatban. A legelterjedtebb és legjelentősebb magzati szövődmény a microcephalia. Ennek jelentőségét az adja, hogy születés után súlyos mentális retardáció kísérheti, mivel a betegségben a koponya mérete és az agyállomány csökkent, amiből következik, hogy az idegsejtek száma is csökken.

A lehetséges kapcsolat a fertőzés és a microcephalia, valamint a neurológiai szövődmények között gyorsan megváltoztatta a Zika-vírus megítélését az enyhe fenyegetésról a riasztó mértékűre. A microcephalia megnövekedett incidenciája egy figyelmeztető jel arra, hogy rendkívül komolyan kell venni a járványt, mivel a magzati károsodások kialakulása hatalmas terhet ró a családra és a társadalomra [3].

\section{Epidemiológia}

A Zika-vírus a Flaviviridae családba tartozó arbovírus, a West Nile, Dengue- és sárgalázvírusokhoz hasonlóan. Ez egy szúnyog által terjesztett megbetegedés, amelynek legföbb vektorai az Aedes aegypti és az Aedes albopictus, ez utóbbi megtalálható Európában és Amerikában is [4]. A vektorok fóleg a nappal folyamán csípnek, és széles körben elterjedtek a trópusi és szubtrópusi régiókban. $\mathrm{Az} A$. albopictus mérsékeltebb éghajlatú területeken fordul elő, mint az $A$. aegypti, így szélesítve a területet, ahol járványok törhetnek ki [5].

2007-ig a Zika-vírus sporadikus humán infekciókat okozott Afrikában és Ázsiában. 2007-ben a Mikronéziai Szövetségi Államok területéről, a Yap szigetről jelentettek fertőzéses eseteket. Ezek voltak az első detektált esetek, amelyeket az endémiás területeken kívül észleltek. Azóta a vírus elterjedt Francia Polinéziában, Új-Kaledóniában, a Cook-szigeteken, Chilében és a Brazíliától Kolumbiáig terjedő régióban is. A Zika-vírusról úgy tartották, hogy nem okoz súlyos megbetegedést. Ez a elképzelés egészen 2013-14-ig volt helytálló, amikor Francia Polinéziában észleltek újabb megbetegedéseket, ahol 28000 esetet jelentettek az első négy hónapban, amely egyrészt súlyos neurológiai - mint a Guillain-Barré-szindróma vagy meningoencephalitis -, másrészt autoimmun - mint a thrombocytopeniás purpura vagy leukopenia - következményekkel jártak $[4,6]$. Ezután a szigetcsoport minden részén elterjedt a vírus. Amerikában 2014-ben ütötte fel fejét a fertőzés [7]. 2015. április és november között a 27 brazil állam közül 18-ban jelentettek eseteket [8]. Az 1. ábra foglalja össze a vírusfertózéseket hely, időpont és esetszám szerint [8].

2016. február elsejére 28 országból jelentettek Zikafertőzést, leginkább Amerikából. Két okból terjedt el ilyen gyorsan ezen a területen a vírus. Az egyik ok, hogy a populáció immunológiailag „érintetlen” a vírussal szemben, a másik a mindenütt jelen lévő Aedes szúnyogok, amelyek megtalálhatók az Amerikai Egyesült Államok déli részétől egészen Argentína északi részéig, kivéve Chile szárazföldi részét. Ez a terület körülbelül 500 millió embert jelent. A World Health Organization szerint az elkövetkező 12 hónapban 3-4 millió Zika-fertőzés történhet, az aszimptomatikus eseteket is beleszámítva [3]. 2014. január és 2016. február között 33 ország jelentett Zika-vírus-fertőzést [9]. Augusztusi adatok szerint már Lengyelországban is jelentettek három esetet, valamint New Yorkban 3000 pácienst vizsgálva 400-at találtak pozitívnak. A megbetegedések valószínúleg behurcolt fertőzésekből erednek, és 13 újszülöttnél igazolták a fertőzöttséget.

Az utóbbi időben a vektor által terjesztett megbetegedések új területeken jelentek meg. Az elmúlt öt évtizedben a patogének terjedésének hajtóereje a kereskedelem fellendülése és az utazások gyakoriságának növekedése volt. Az interkontinentális légi forgalom növekedése lehetővé tette a globális tranzitot, így felgyorsította a pato- 


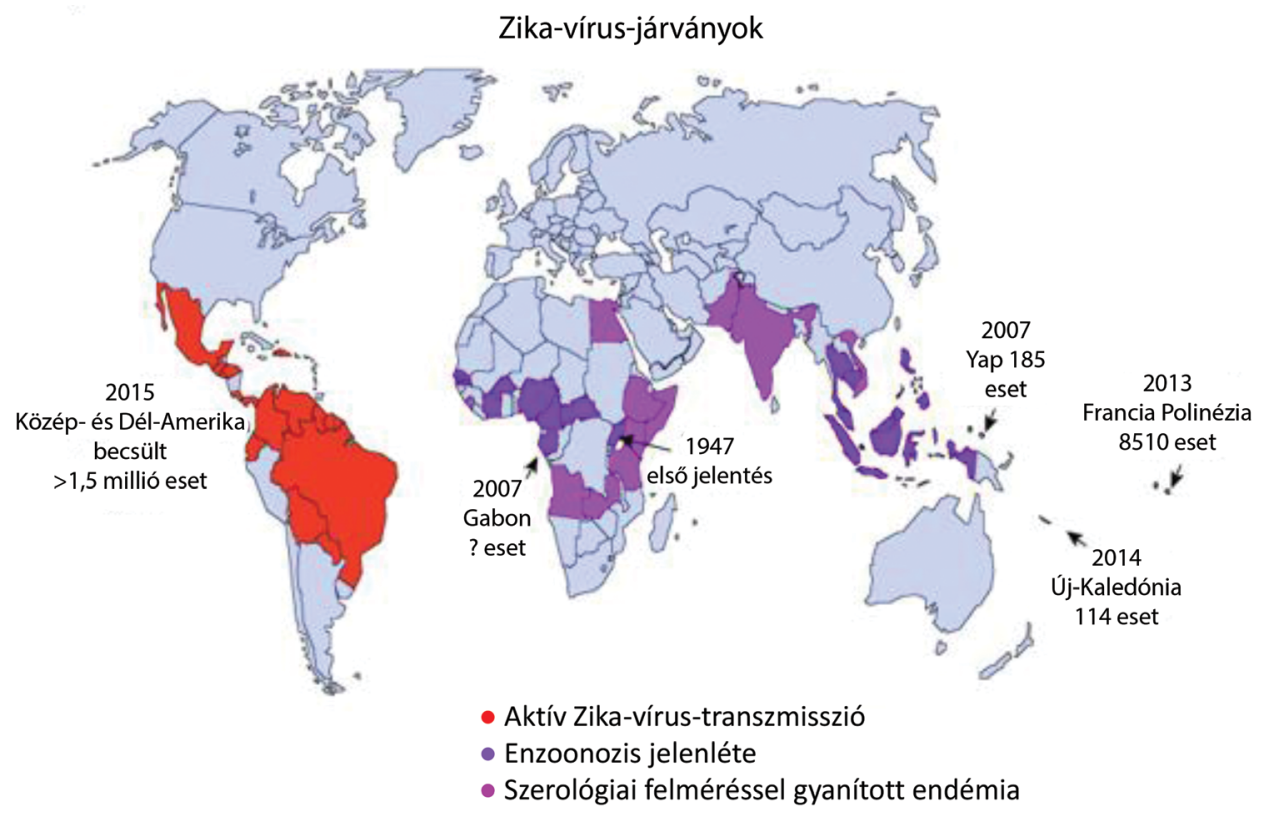

1. ábra

| A Zika-vírus-fertőzés globális térképe a jelentett esetek számával 2015-ig [8]

gének rövid időn belüli terjedését különböző kontinensekre, ahol olyan vírusgazdák vannak, amelyek a latens periódus alatt is fertőzőképesek.

A környezeti faktorok is jelentős szerepet töltenek be a patogének terjedésében. Az amazoni és kelet-afrikai erdőirtás növeli az állóvíz és a napsütés mennyiségét, valamint elősegíti a vírusok sikeres szaporodását. A lakosság elvándorlása polgárháború vagy természeti katasztrófa miatt szintén növeli a kontaktust az ember és a vektor között. A vektor által terjesztett patogének általában rendkívül érzékenyek az időjárásra, de ezen tényező a fentebb említettekhez képest kevésbé fontosnak bizonyult. A klímaváltozás hatása, hogy sokkal elszórtabban és gyakrabban alakulnak ki vektor által terjesztett betegségek. Ez annak köszönhető, hogy az éghajlat egyre jobban hasonlít a trópusokéhoz, ahol az adott patogének gyakrabban fordulnak elő. A hőmérsékletnek nagy szerepe van a felnőtt vektorok túlélésében, a vírusreplikációban és a fertőző periódusban [10]. A magas hőmérséklet kibővíti a vektorskálát, csökkenti a patogén inkubációs idejét és növeli a nőstény szúnyogok harapási gyakoriságát. Azonban a csapadék biztosítja a lárvák megfelelő környezetét az Aedes szúnyogok életciklusának adott stádiuma alatt [11]. Brazíliában az éghajlati viszonyok, a szúnyogok tetemes mennyisége és a sűrűn lakott, a fertőzéssel szemben immunológiailag érintetlen populáció elősegíti a fertőzés terjedését [4].

A vírus egyik átviteli módja a szexuális úton való terjedés, ha az endémiás területre utazó férfi Zika-vírus-fertőzéssel tér haza. Valószínúleg a vírus replikálódni tud a férfi genitális traktusban és így betölti a speciális rezervoár szerepét. Következésképpen, a terhes nőknek nemcsak a szúnyog elleni védekezésre kell odafigyelniük, hanem a partnerükkel való szexuális együttlétre is, legalább a terhességük alatt [12]. Egy másik lehetséges transzmissziós út a transzfúzió. A vírus megtalálható továbbá az anyatejben is, hasonlóan a többi arbovírushoz, de eddig nem támasztották alá, hogy az újszülöttre nézve ez fokozott kockázatot jelentene $[13,14]$.

2016. novemberben Salt Lake Cityben történt egy halálos kimenetelü vírusfertôzés, ahol a beteg másodlagosan, nem szexuális úton fertőzte meg a közvetlen közelében tartózkodó személyt. Az első páciens egy 73 éves férfi, aki Mexikóból emigrált az Egyesült Államokba. Hypotensio és hasi fájdalom miatt került felvételre, anamnézisében prosztatadaganat diagnózisával. A kórházba kerülése előtt egy hónappal megkapta a szükséges sugárterápiát. A tünetek megjelenése előtt három hetet töltött Mexikó délnyugati részén, ahol a fertőzött egyének száma magas. A fenti tünetei mellett conjunctivitis, lágy szájpadi petechiák, hasmenés és tachypnoe jelentkezett. A szérumában kiemelkedően nagy mennyiségben találtak víruskópiaszámot. Állapota progresszíven romlott, majd a többszervi elégtelenség és a metabolikus acidózis miatt exitált. A második páciens meglátogatta a kórházban az első beteget, ahol gumikesztyű használata nélkül segített a nővérnek repozicionálni őt és kitörölte a beteg szemét is. Néhány nappal ezt követően észlelte a vírusfertőzés tüneteit. A szérum- és vizeletmintája pozitív lett Zika-vírusra. Mivel ő a megelőző kilenc hónapban nem utazott endémiás területre és nem létesített szexuális kapcsolatot olyan emberrel, aki ilyen területről érkezett, valószínűsíthető, hogy az első betegtől kapta el a fertőzést az izzadsággal vagy könnyel való érintkezés útján.

Ez az eset felhívja a figyelmet arra, hogy a nem immunhiányos egyének fertőződése is lehet halálos, valamint, hogy intakt bőrön vagy nyálkahártyán keresztül is el lehet kapni a betegséget [15]. 
2016. július elején egy 23 hetes terhes jelentkezett a floridai kórházban. Törzsén és karján erythematosus, follicularis maculák, tenyerén halvány piros papulák, a kemény szájpadon petechiák jelentkeztek. A fizikális vizsgálat egyéb tüneteket nem mutatott. A nő széruma és vizelete Zika-vírusra pozitív lett. Az eset jelentőségét az adja, hogy sem az anya, sem a partnere nem hagyta el az Egyesült Államok területét, így nem volt jelentős kockázatuk a fertőzésre, ezenfelül sem a magzatban, sem pedig a placentában nem találtak a vírusra utaló jeleket [16].

\section{Patomechanizmus}

Sajnos még nem rendelkezünk megfelelő információval a vírus fertőzésének mechanizmusáról és csak feltételezésekből következtethetünk arra, hogy a Zika milyen módon vezet a microcephalia és egyéb súlyos neurológiai megbetegedések kialakulásához. A mechanizmus pontos ismerete elősegíti a korai diagnosztikus eljárások kifejlesztését és a későbbi járványok megelőzését.

Kétféle hipotézis létezik a placenta lehetséges szerepére. Az egyik, hogy a placenta közvetlenül továbbítja a vírust az embrió vagy magzat felé, a másik, hogy a placenta maga felerôsíti az expozícióra adott választ, és ez a válasz járul hozzá, hogy kialakuljon az agy károsodása.

Az egyik teória szerint a vírus rendelkezik neurotrop tulajdonságokkal és a placentán keresztül hozzáfér és károsítja a fejlődésben lévő agyat. Ez a hipotézis feltételezi a vírus jelenlétét a magzatban, a cortex kialakulásának korai stádiumában. Mindemellett ebben a korai stádiumban a magzat teljesen védett az anyai keringéstől, mivel az anyai véráramlás a placentában csak a 10. gesztációs héten kezdődik el. A vírus beléphet a méh mirigyeinek szekrécióján át, átszivárog a trophoblastok által alkotott dugón, amely gátolja az anyai vérátáramlást diffúzió útján a magzatvízbe vagy szikzacskóba. Amint a vírus eléri a trophoblastbarriert, nem neutralizáló antitesttel képzett immunkomplex részeként a placentán keresztül szállítódik Fc-gamma-receptorok segítségével. Ez a folyamat nem valószínú, hogy megtörténik a 16. terhességi hét előtt. A Zika-vírus a trophoblast endoplazmatikus reticulumába kerül, hogy a placentalis exoplazmák szállítmányaivá váljon. Ezen exoszómák az embrionális vagy magzati neuroepitheliumot veszik célba. A vírus lokális reakciót okoz a placenta felületén, amely szabad utat enged a vírus átjutásához (2. ábra) [14].

Más teóriák szerint a Flavivírusoknak, a STAT-2 jelátviteli molekula degradációjának indukálásával, le kell küzdeniük az I. típusú interferonreceptor jelátviteli útját ahhoz, hogy szaporodni tudjanak a sejtekben. A STAT-2 egy olyan protein, amely képes befolyásolni az interferonreceptor múködését. A Zika-vírus képes szaporodni a trophoblastokban, endothelsejtekben és a placenta Hofbauer-macrophagjaiban is. Így nem meglepő, hogy vírus-RNS-t azonosítottak ezeken a sejteken belül is. A sejt-vírus interakciót elősegíti a sejtfelszínen elhelyezkedő tirozinkináz-receptor, az AXL. Kora terhességben a

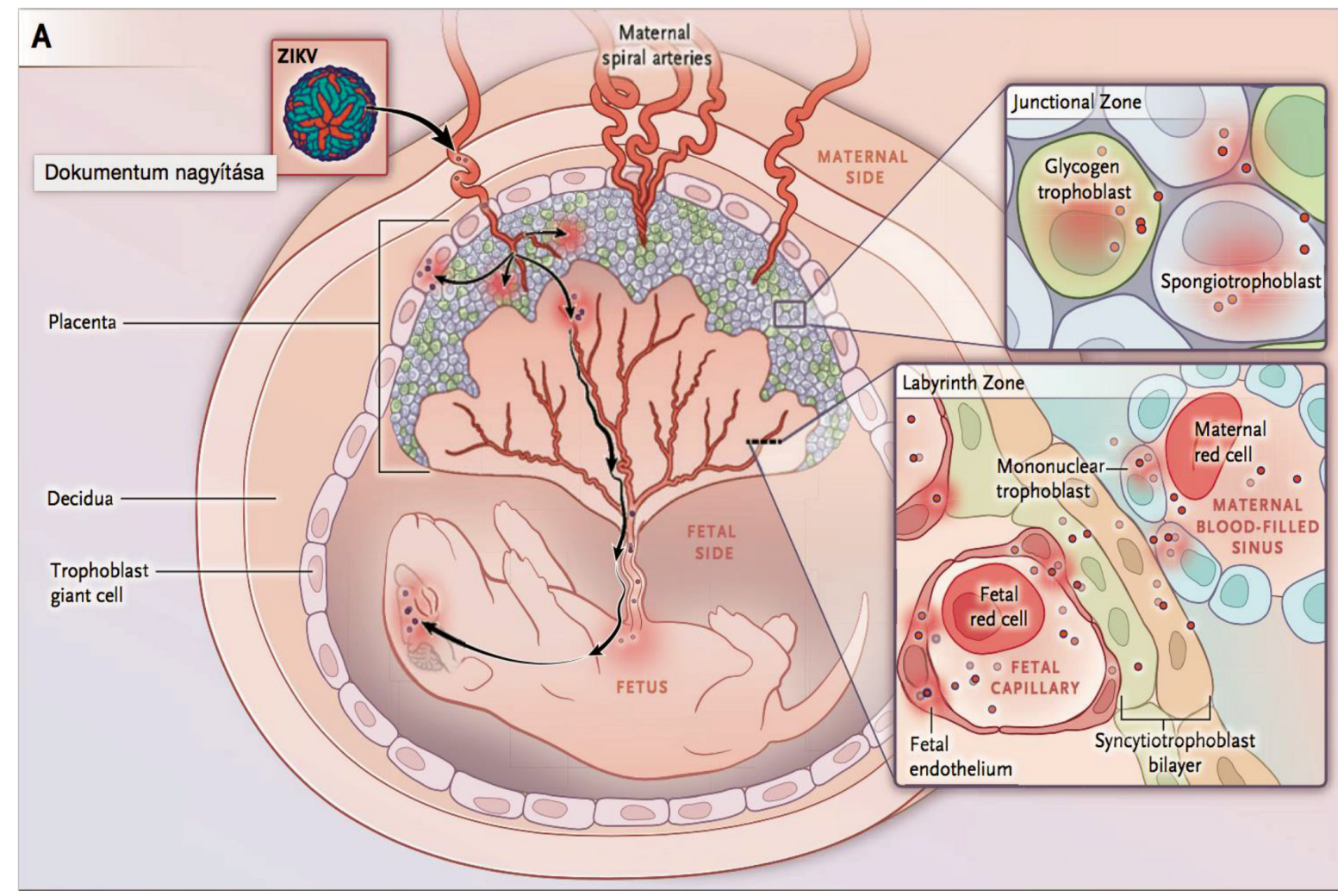



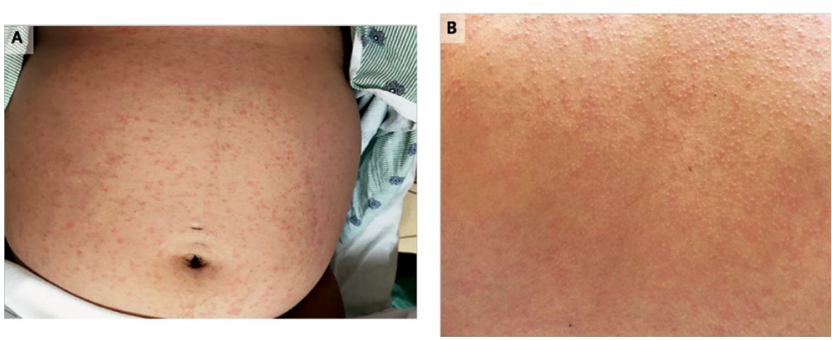

3. ábra

| Zika-vírus-fertôzés során megjelenő kiütések [16]

vírusfertőzés súlyos vascularis károsodást idéz elő a placentában, valamint redukálja a magzati erek számát és csökkenti az áramlást. A vírus anélkül is át tud jutni, hogy súlyosabb károsodást idézne elő, majd ez után szétterjed a magzati agyban, megfertózi és károsítja az idegsejteket. Ennek elófordulása inkább a terhesség késői szakaszában való fertőződéskor gyakori, mivel ilyenkor erősebb az interferon indukálta veleszületett immunitás a trophoblastokban [17].

\section{Zika-vírus-fertőzés által okozott tünetek}

A szúnyogcsípés után a tünetek néhány nap után jelentkeznek, körülbelül egy hétig tartanak. Öt emberből egy jelez enyhe panaszokat, a súlyos tünetek miatti hospitalizáció nem gyakori [3].

Láz, fejfájás, myalgia, arthralgia, rossz közérzet, nonpurulens conjunctivitis és retroorbitalis fájdalom jelentkezhet. Előfordulhatnak még maculopapulosus kiütések, ödéma és hányás, ritkábban haematospermia, tranziens süketség, a kéz és boka duzzanata, valamint subcutan vérzések $[5,6,13]$.

Súlyosabb esetben előfordulhat tachycardia, hypotensio, tachypnoe és veseelégtelenség is [18].

A 3. ábrán láthatók egy terhes nő hasán (A) és hátán (B) lévő erythematosus maculák és papulák [16].

\section{Microcephalia}

A microcephalia a leggyakrabban előforduló betegség, amelyet a vírusfertőzés kapcsán jelentettek. A microcephalia definíciója nem egységes, de általában a nemnek és kornak megfelelő fejtérfogat-értéktől több mint 2

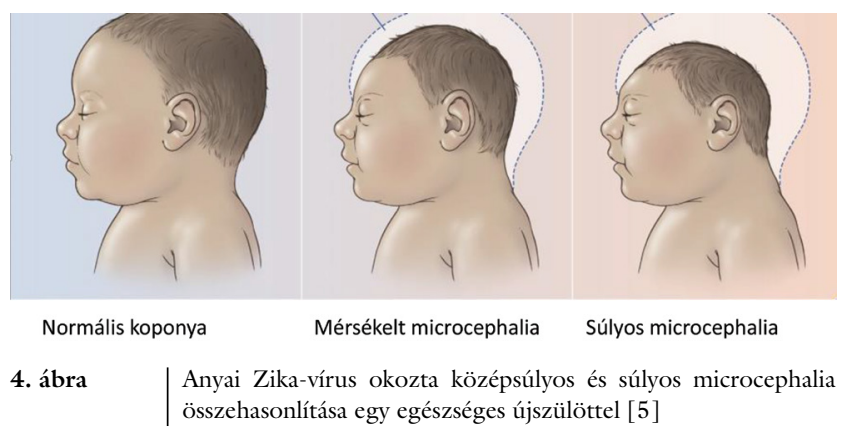

standard deviációval való eltérést jelenti. A fejkörfogat nagy különbségeket mutat a populáción belül. A 4. ábra mutatja a microcephalia súlyossági fokait [5].

Miután a Zika-vírus felbukkant Brazíliában, évi húszszoros növekedést figyeltek meg az ebben a betegségben szenvedók számában. 2015-ben 1248 új, gyanús esetet jelentettek. A fertőzés prevalenciája 100000 élveszületésre 99,7. Brazíliában 4783 microcephaliás esetet jelentettek 2015. október és 2016. január 30-a között. Ez rendkívül jelentős emelkedésnek számít, mivel 2001 és 2014 között ez a szám 163 volt évente, ennek majdnem 80\%-a Északkelet-Amerikából származott [9].

Számos esettanulmány támasztja alá, hogy a microcephalia oka a direkt transzfer lehet. A tanulmányokban a magzat expozíciója, az anyai tünetek alapján, az első trimeszter késői szakában történik. A primer microcephalia a domináns típus, amely a korai neurogenezis alatt jön létre. A fő́bb jellegzetességek a kisebb neuronszám, a simább gyrusfelszín és a kisebb méretü agy. Egyrészről a placenta proinflammatorikus válasza megzavarhatja az embrió agyának normális fejlődését. Másrészről a korai placenta által szintetizált molekulákban és jelátviteli utakban zavar keletkezik, a microcephalia génjeihez hasonlóan. Ilyen gén a CASC5, MCPH1-12. Ezeknek a géneknek a túlzott vagy alulmúködése a placentában vagy a magzatban hozzájárulhat a magzati defektusok kialakulásához [19].

A vírus célsejtjei a fejlődő magzatban még ismeretlenek. Tang és kollégái kutatásaik során rájöttek, hogy in vitro körülmények között a vírus az emberi neuralis progenitor sejteket (hNPCs) fertőzi meg, amelyek a pluripotens őssejtekből származtathatóak. Később ezek a sejtek víruspartikulumokat bocsátanak ki, ami nagy kihívást jelent a hatásos gyógykezelés megtalálásának szempontjából. Az infekció kaszpáz-3-mediált sejthalált idéz elő és beleavatkozik a sejtciklus folyamatába, ezzel legyengítve a hNPCs-sejteket [20].

Számos egyéb tényező vezethet a kialakulásához, mint például a genetikai és környezeti tényező́k, amelyek a terhesség alatt hatással vannak a magzatra. A genetikai faktorok között szerepelhetnek monogénes betegségek vagy aneuploidia. Ezenfelül praenatalis vírusinfekciók (CMV, rubeola), anyai alkohol- és kokainabúzus, alfahemolizáló streptococcus és hipertenzív megbetegedések szerepelnek az etiológiai faktorok között [19].

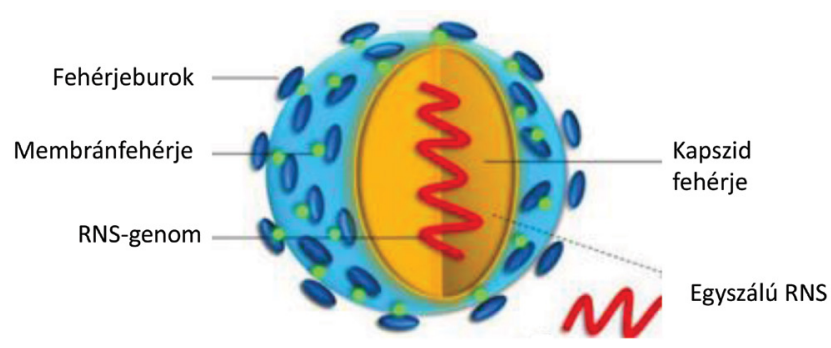

\begin{tabular}{l|l} 
5. ábra & A Zika-vírus szerkezete és genomja [27]
\end{tabular} 
A microcephalia súlyos szövődményekhez vezet. Ezek közé tartozik a mentális retardáció, cerebralis paralysis, rohamok, szenzorineurális süketség és a látás csökkenése.

A tünetmentes fertőződés terhesség alatt nem jelent biztosítékot a microcephalia kifejlődése ellen. Mint ahogy más teratogén vírusfertőzésnél, a Zika-vírusnál is valószínútlen, hogy a magzatok 100\%-ában kialakulnak tünetek [21].

\section{Guillain-Barré-szindróma}

A szindróma kialakulásának aránya 0,24 1000 Zika-fertőzésre vonatkoztatva. A Guillain-Barré-szindróma kialakulásának kockázata a korral nő, és általában a férfiakat érinti gyakrabban a megbetegedés. Az aszimptomatikusan zajló fertőzésnél sokkal kisebb az esélye a megbetegedés bekövetkezésének, mint a szimptomatikus esetekben [22].

Ez egy akut, autoimmun, poliradiculoneuropathia, amely általában vírus- vagy baktériumfertőzés után kettő-nyolc héttel alakul ki. A flaccid paralysis az alsó végtagokon kezdődik és proximalis irányba halad tovább. A betegséget általános gyengeség, areflexia és a sensorium eltérései kísérik.

Mivel ez egy demyelinisatiós betegség, amely az axonokat is érinti, így EMG-vizsgálattal az axon vezetési sebessége és amplitúdójának csökkenése mutatható ki [23]. A Flavivírus-nemzetségen belül gyakran keresztreakció figyelhető meg, amely a fertőzésükre adott immunválaszt is befolyásolja, ezzel előidézve a korai, nem megfelelö antitesttermelést [22].

A betegség immunoglobulinokkal és plazmaferézissel kezelhető [24].

\section{A fertőzés diagnosztikája}

$\mathrm{Az}$ anamnézis, mint minden megbetegedés esetében, itt is a legelső és legfontosabb lépés a diagnózis megszerzése felé. Az endémiás, fertőzött területről való hazatérés a tünetek jelenlétében már felkeltheti a vírusfertőzés gyanúját. Nem specifikus és rendkívül hasonló tüneteket okoz, mint a többi egzotikus arbovírus. Ez differenciáldiagnosztikai problémákhoz vezet, így fontos elkülöníteni a Dengue- és a Chikungunya-láztól [25].

A fertőzés laboratóriumi jellemzője az aktivált lymphocyták megjelenése, valamint a thrombocytopenia, mérsékelt leukopenia, néhány jellemzően súlyosabb esetben metabolikus acidózis [26].

A Zika egy burokkal rendelkező, ikozaéder alakú vírus, amelynek genomja egyszálú, pozitív RNS-molekulából áll. A poliprotein prekurzorok, virális és celluláris proteázok segítségével virális fehérjékre hasad. A C a kapszid, a prM a prekurzor membrán, az E a burokfehérje és az NS a nem szerkezeti fehérjéket takarja. Az Envelope fehérje alkotja a vírus külső felszínének nagy részét és ez a gazdasejt megkötésével és fúziójával részt vesz a replikáció folyamatában. Az NS1, 3, 5 nagy, erôsen konzervált fehérjék, míg az NS2A, 2B, 4A, 4B kisebb hidrofób fehérjék. A vírus szerkezete a többi Flavivíruséhoz hasonló. Tartalmaz egy 25-30 nm átmérőjű nukleokapszidot, és maga a virion 40 nm átmérôjű (5. ábra) [27].

Egy korábbi genetikai vizsgálat alapján, amely az NS5 gén nukleotidszekvenciáját használta, a vírus három rokonsági ágát fedezték fel. Ezek az ázsiai, nyugat- és kelet-afrikai [28].

A Zika-vírus kimutatása nehézségekbe ütközhet, mivel az immunológiai assayvizsgálatok nem specifikusak a szerológiai keresztreaktivitás miatt a Zika- és a Denguevírus között. A friss mintából való molekuláris detektálás lenne a legmegfelelőbb eljárási mód, de a vírus általában csak a tünetek megjelenése után, négy-öt napig marad a fertőzött egyén vérében, ami korlátozza a diagnózis létrejöttének idejét [8]. Ezzel szemben a vizeletben néhány nappal tovább is ki lehet mutatni a vírus-RNS-t.

A Zika-vírus rutindiagnosztikája a vírusnukleinsav detektálása reverz transzkripciós polimeráz láncreakció (RT-PCR) segítségével, valamint az IgM-antitestek kimutatása enzimkötött immunoszorbens esszé (MACELISA) technikával. Az RNS szérumban való jelenléte definitív diagnózist nyújthat, azonban a legtöbb esetben a viraemia átmeneti és az RT-PCR sikeresebb a tünetek megjelenése után egy héttel. Ezzel ellentétben előfordulhat prolongált viraemia is. Ezt alátámasztó eset történt 2016 decemberében, Kolumbiában. Egy kilenchetes, Zika-vírussal fertőzött gravida szérumában 107 napig, a tünetek megjelenésének kezdetétől számítva lehetett kimutatni a vírust a láncreakció segítségével. Ez a magzatban és a placentában történő vírusreplikációnak eredménye, így rezervoárnak tekinthetők [29].

A plakkredukciós neutralizációs teszt (PRNT) a legspecifikusabb eljárás az egymáshoz közel álló vírusok antitestjeinek elkülönítésében, és ez segítséget nyújthat MAC-ELISA eredményének megerősítésében. Sajnos ez az eljárás túl költséges, csak bizonyos laboratóriumokban kivitelezhető, élő vírus kezelését igényli, és legalább egy hét, mire az eredmények prezentálhatók [5].

A vírust a magzatvízben, placentában és a magzat szöveteiben is kimutatták [4]. Ezenkívül az ondóban, nyálban, vizeletben és az anyatejben is találtak már fertőző víruspartikulumokat.

Terhesség során diagnosztikus céllal végezhető amniocentesis, viszont ennek hátránya, hogy növeli a vetélések gyakoriságát. Abban az esetben végezhető, ha magzati károsodásra utaló jelek láthatók vagy hat-nyolc héttel az anyai expozíció után, de semmiképpen sem a 21. gesztációs hét előtt. Ennek oka, hogy a vírus csak akkor jelenik meg a magzatvízben, ha már a magzati vese képes elegendő vizelet termelésére a 18. és 22. hét között, és ha ez megtörtént, a vírus át tud jutni a placentabarrieren, ez az anyai fertőződés utáni hatodik-nyolcadik hétre esik [30]. 


\section{Stratégiák a járvány terjedésének megelőzésére}

A természetes és szerzett immunitásnak nincs protektív hatása emberekben, és az expozíciót a vektorral való kontaktus szabályozza. Ebből adódóan a járvány terjedésének megelőzésében elsődleges szerepet kapnak az endémiás területeken alkalmazható stratégiák.

Endémiás területeken a zoonozisok kontrollja nehéz, eradikációjuk pedig egyszerúen lehetetlen. A vektor által terjesztett patogének transzmissziója frekvenciadependens, így az állatállomány szelektálása csökkenti a vírusgazda sűrűségét, de növelheti a kórokozó átvitelét. A vektorok valószínúleg megtalálják és megfertőzik a megmaradó vírusgazdákat, így az egy gazdára jutó vektorok száma növekszik.

A vektorkontroll-stratégiák kidolgozása szempontjából fontos kideríteni az elsődleges és a lehetséges vektorokat, mert a járvány megfékezésének és a szövődmények csökkentésének érdekében ezeknek a megfelelő cél ellen kell irányulnia [31]. Brazíliában különböző rovarirtókat és ETD-kek vetnek be a szúnyogok ellen, valamint larvicid adalékot adnak a vízhez. Sajnos ezzel nem érik el a kívánt hatást, ugyanis sok város nem vezetékes vízhálózatból szerzi be ivóvizét, amely hozzájárul a szúnyogok elszaporodásához. Más nézőpontból megközelítve, a városi infrastruktúra és a környezeti higiénia fejlesztése, hordozható, tisztavíz-ellátmánnyal a rászorultaknak elősegítené a vektorok elleni védekezést [32]. Sajnos az erőfeszítések ellenére a vektor kontrollja nem éri el a kellő hatásfokot. A járvány megfékezésére még két újabb lehetőség adódik. Az egyik a vektorok genetikai kontrollja, a másik pedig az olyan szúnyogok felfedezése, amelyek ellenállóak az arbovírusokkal szemben. Az első genetikaikontroll-stratégia neve a RIDL (the Release of Insects carrying Dominant Lethal genes). Ez magába foglalja az Aedes aegypti tömegtenyésztését, amelyet genetikailag úgy módosítottak, hogy elnyomható letalis gént hordozzanak. A tenyésztés alatt tetraciklinnel elnyomták ezeket a géneket. Csak a hím szúnyogokat engedték szabadon, így azok párosodni tudtak a vadon élő nőstényekkel, viszont utódaik, mivel nem kaptak a gyógyszerből, nem jutottak el a felnőtt stádiumig.

A másik lehetőség, hogy endoszimbionta baktérium használatával meggátolhatják az arbovírusok szaporodását a szúnyogokon belül. Korábban már alkalmazták ezt az eljárást a Wolbachia baktériummal a Dengue-járvány idején.

Ezen eljárások legnagyobb előnye, hogy környezetbarátok, fajspecifikusak és csökkenthetik a rovarirtók használatát. Ezek a kontrollstratégiák jó alapot nyújthatnak a Zika-vírus által okozott járvány terjedésének megfékezésére [33]. Az Országos Epidemiológiai Központ 2017. február 9-én publikált tájékoztatója szerint az Európai Unió területén eddig néhány esetben fordult elő utazással összefüggő, behurcolt Zika-vírus-fertőzés. Európában honi eredetü megbetegedést még nem diagnoszti- záltak. Az ECDC javasolja a tagállamoknak, hogy fordítsanak fokozott figyelmet a Zika-vírus-fertőzések behurcolásának lehetőségére, fóleg azokban az országokban, ahol a kórokozó terjesztésére alkalmas vektorok megtalálhatóak, annak érdekében, hogy elkerüljék a vírus hazai terjedését [34]. Tájékoztassák a klinikusokat és az utazási medicinával foglalkozó egészségügyi szolgáltatókat a Zika-járványról, az endémiás területekről, hogy az érintett területről érkező utazók megbetegedése esetén gondoljanak a Zika-vírusra is a differenciáldiagnosztika során. A jelenleg Zika-vírus-járvánnyal érintett országokból hazatérő lázas, kiütéses betegnél, ha a Dengue- és a Chikungunya-vírus kóroki szerepe kizárt, megfontolandó a Zika-vírus etiológiai szerepének tisztázása. Szorgalmazzák, hogy az európai régióban erősítsék meg a Zika-vírus-gyanús megbetegedések laboratóriumi kivizsgálására irányuló kapacitást, hogy az esetleges Zikavírus-fertőzéseket el tudják különíteni más, a Denguehez hasonló arbovírus-infekcióktól [34].

\section{Kezelés és a vírusfertőzés prevenciója}

Eddig még nincs bizonyítottan hatásos kezelés, amelynek biztonságosnak kell lennie a terhes anyák számára is. Ehhez a vírusról több tudás megszerzésére van szükség, fóleg azért, hogy megóvjuk a magzatokat súlyos és maradandó kárt okozó congenitalis malformatiók kialakulásától.

Még nincs specifikus antivirális szer a fertőzés ellen. A kezelés alappillére az ágynyugalom és a szupportív terápia, amely láz- és fájdalomcsillapításból, valamint bő folyadékfogyasztásból áll [35]. A lázat általában paracetamoltartalmú gyógyszerrel célszerü csökkenteni. Az aszpirint és egyéb nem szteroid gyulladáscsökkentőket általában nem használják terhesség alatt, ezeket főleg addig kell elkerülni, amíg a Dengue-vírus-fertőzést kizárják, megelőzve ezzel a vérzés kialakulását [36].

A lehetséges prevenciós technikák közül az egyik a személyi védelem, mint a szúnyogriasztó használata, a másik a szúnyogcsípés elkerülése nappal [37]. A National Institute of Allergy and Infectious Disease már dolgozik hatásos oltóanyag kifejlesztésén. Törekvéseik DNS-alapú vakcinák kidolgozása felé irányul, hasonlóan ahhoz, amit a West Nile vírus ellen fejlesztettek ki. 2016 júliusától már embereken is elkezdték tesztelni az oltóanyag hatásosságát. Egy másik lehetőség az élő vírust tartalmazó vakcina, hasonlóan a Dengue-vírus elleni oltóanyaghoz. Harmadik lehetőségként felmerül az mRNS-tartalmú vakcina is. A pennsylvaniai egyetemen egereket és rhesus majmokat oltottak be egyetlen, kis dózisú intradermalis lipid nanorészecskéket tartalmazó, tokban lévő, nukleozidmódosított mRNS-sel. Tapasztalataik alapján gyors és hosszan tartó védettség alakult ki az immunizált állatokban [38]. Jelenleg nem áll rendelkezésre és sajnos valószínúleg a közeljövőben sem fog rendelkezésünkre állni hatékony és biztonságos vakcina a Zika-vírus-fertőzés ellen. Előreláthatólag három-öt éven 
belül jelenhet meg a megfelelő oltás [3]. A vakcina kifejlesztése elengedhetetlen a hosszú távú védelem kialakításához [30].

A World Health Organization azt tanácsolja a várandósoknak, hogy használjanak DEET-tartalmú szúnyogriasztót, takarják el a testüket, amennyire csak lehet hoszszú, világos ruhákkal, valamint használjanak tiszta, üres palackot a víz tárolására és szúnyoghálóval védve aludjanak [3]. A latin-amerikai kormány kifejezetten ajánlotta a fertilis korú nőknek és pároknak, hogy a Zika-vírusjárványra való tekintettel halasszák el a gyermekvállalás időpontját. Az ajánlás alapját az képezi, hogy a régióban a terhességek $56 \%$-a váratlanul következik be. A szegényes szexuális felvilágosítás, a fogamzásgátlók hozzáférhetőségének nehézsége, a nemi erőszak magas prevalenciája hozzájárul a fertőzés terjedéséhez. Felmerül az abortusz lehetősége, de ez törvény által szabályozott eljárás. A járvány sporadikus és kiszámíthatatlan terjedése miatt a lakosság megelőző beoltása megfizethetetlenül drága lenne [35].

Az Országos Epidemiológiai Központ 2016 nyarán rendkívül részletes ajánlást tett közzé a Zika-vírus-fertőzések megelőzésével kapcsolatos teendőkről, s az legutóbb 2017. február 9-én került frissítésre [34]. A téma napról napra frissülő ismeretanyaga némi korrekciót tesz indokolttá. Ilyen például a szexuális kapcsolat útján való terjedésnél jelzett hat hónapos absztinencia, illetve barrier védekezés, ami mai ismereteink szerint már túlhaladottnak tekinthető, hiszen a vírusclearance ettől lényegesen gyorsabb [39]. Ma már szintén túlhaladottnak tekinthető az ajánlás utolsó bekezdése a Zika-fertőzött beteg ápolását végző személy veszélyeztetettségének elvetéséről, hiszen az első nem endémiás területen (Amerikai Egyesült Államok) akvirált eset is pontosan ilyen módon szerezte a fertőzést [15]. A hazai hivatalos ajánlás nagyrészt az ECDC ajánlásain alapul, ami a javított kézirat beadását megelőzően, 2016. november 25-én volt frissítve utoljára, és az új adatok akkor még nem voltak ismertek [40].

Anyagi támogatás: A közlemény megírása és a hozzá kapcsolódó kutatómunka anyagi támogatásban nem részesült.

Szerzői munkamegosztás: V. G.: Az információk rendszerezése, a közlemény megírása és szerkesztése. P. R.: Témafelvetés, szisztematikus irodalomkutatás, a kézirat szerkesztése. A cikk végleges változatát mindkét szerző elolvasta és jóváhagyta.

Érdekeltségek: A szerzőknek nincsenek érdekeltségeik.

\section{Irodalom}

[1] Dick, G. W., Kitchen, S. F., Haddow, A. J.: Zika virus. I. Isolations and serological specificity. Trans. R. Soc. Trop. Med. Hyg., 1952, 46(5), 509-520.
[2] Enfissi, A., Codrington, J., Roosblad, J., et al.: Zika virus genome from the Americas. Lancet, 2016, 387(10015), 227-228.

[3] Samarasekera, U., Triunfol, M.: Concern over Zika virus grips the world. Lancet, 2016, 387(10018), 521-524.

[4] Solomon, T., Baylis, M., Brown, D.: Zika virus and neurological disease - approaches to the unknown. Lancet Infect. Dis., 2016, 16(4), 402-404.

[5] Petersen, L. R., Jamieson, D. J., Powers, A. M., et al.: Zika virus. N. Engl. J. Med., 2016, 374(16), 1552-1563.

[6] World Health Organization: Zika virus outbreaks in the Americas; Malaria situation. Wkly Epidemiol. Rec., 2015, 90(45), 609-616.

[7] Editorial: Zika virus in the dock. Lancet Infect. Dis., 2016, 16, 265.

[8] Ventura, C. V., Maia, M., Bravo-Filho, V., et al.: Zika virus in Brazil and macular atrophy in a child with microcephaly. Lancet, 2016, 387(10015), 228.

[9] Zwizwai, R.: Infection disease surveillance update. Lancet Infect. Dis., 2016, 16(2), 157.

[10] Kilpatrick, A. M., Randolph, S. E.: Drivers, dynamics and control of emerging vector-borne zoonotic disease. Lancet, 2012, 380(9857), 1946-1955.

[11] Paz, S., Semenza, J. C.: El Niño and climate change - contributing factors in the dispersal of Zika virus in the Americas? Lancet, 2016, 387(10020), 745.

[12] Mansuy, J. M., Dutertre, M., Mengelle, J., et al.: Zika virus: high infectious viral load in semen, a new sexually transmitted pathogen? Lancet Infect. Dis., 2016, 16(4), 405.

[13] Cao-Lormeau, V. M., Musso, D.: Emerging arboviruses in the Pacific. Lancet, 2014, 384(9954), 1571-1572.

[14] Dupont-Rouzeyrol, M., Biron, A., O'Connor, O., et al.: Infectious Zika viral particles in breastmilk. Lancet, 2016, 387(10023), 1051.

[15] Swaminathan, S., Schlaberg, R., Lewis, J., et al.: Fatal Zika virus infection with secondary nonsexual transmission. N. Engl. J. Med., 2016, 375(19), 1907-1909.

[16] Chen, L., Hafeez, F., Curry, C. L., et al.: Cutaneous eruption in a U.S. woman with locally acquired Zika virus infection. N. Engl. J. Med., 2017, 376(4), 400-401

[17] Mysorekar, I. U., Diamond, M. S.: Modeling Zika virus infection on pregnancy. N. Engl. J. Med., 2016, 375(5), 481-484.

[18] Zonneveld, R., Roosblad, J., van Staveren, J. W., et al.: Three atypical lethal cases associated with acute Zika virus infection in Suriname. ID Cases, 2016, 5, 49-53.

[19] Adibi, J. J., Marques, E. T. Jr., Cartus, A., et al.: Teratogenic effects of the Zika virus and the role of the placenta. Lancet, 2016, 387(10027), 1587-1590.

[20] Tang, H., Hammack, C., Ogden, S. C., et al.: Zika virus infects human cortical neural progenitors and attenuates the growth. Cell Stem Cell, 2016, 18(5), 587-590.

[21] Musso, D., Baud, D.: Zika virus: time to move from case reports to case control. Lancet, 2016, 16(6), 620-621.

[22] Smith, D. W., Mackenzie, J.: Zika virus and Guillain-Barré syndrome: another viral cause to add to the list. Lancet, 2016, 387(10027), 1486-1488.

[23] Cao-Lormeau, V. M., Blake, A., Mons, S., et al.: Guillain-Barré syndrome outbreak associated with Zika virus infection in French Polynesia: a case-control study. Lancet, 2016, 387(10027), 1531-1539.

[24] Shakir, R.: Neurological expertise is essential for Zika virus infection. Lancet Neurol., 2016, 15(4), 353-354.

[25] Musso, D., Cao-Lormeau, V. M., Gubler, D. J.: Zika virus: following the path of dengue and chikungunya? Lancet, 2015, 386(9990), 243-244.

[26] Gourinat, A. C., O'Connor, O., Calvez, E., et al.: Detection of Zika virus in urine. Energ. Infect. Dis., 2015, 21(1), 84-86. 
[27] Rekba, M. M., Kumar, A. B., Mubeena, T., et al.: A short review on Zika Virus past, present strategies and future prospectives. PharmaTutor, 2016, 4(7), 21-24.

[28] Haddow, A. D., Schuh, A. J., Yasuda, C. Y., et al.: Genetic characterization of Zika virus strains: geographic expansion of the Asian lineage. PLoS Negl. Trop. Dis., 2012, 6(2), el477.

[29] Suy, A., Sulleiro, E., Rodó, C., et al.: Prolonged Zika virus viremia during pregnancy. N. Engl. J. Med., 2016, 375(26), 261 1-2613.

[30] Barreto, M. L., Barral-Netto, M., Stabeli, R., et al.: Zika virus and microcephaly in Brazil: a scientific agenda. Lancet, 2016, 387(10022), 919-921.

[31] Ayres, C. F.: Identification of Zika virus vectors and implications for control. Lancet Infect. Dis., 2016, 16(3), 278-279.

[32] De Silva Augusto, L., Gurgel, A. M., Costa, A. M., et al.: Aedes aegypti control in Brazil. Lancet, 2016, 387(10023), 10521053.

[33] Yakob, L., Walker, T.: Zika virus outbreak in the Americas: the need for novel mosquito control methods. Lancet Glob. Health, 2016, 4(3), el48-el49.

[34] National Center for Epidemiology: Q\&As about Zika. [Országos Epidemiológiai Központ: Ajánlás a Zika-vírus fertőzés veszélyének kitett várandós nók és a feltehetően Zika vírus által okozott malformációban szenvedő magzatok és újszülöttek kivizsgálásához.] Available from: https://www.antsz.hu/felso_menu/ temaink/jarvany/zika_gyik.html [accessed: February 18, 2017] [Hungarian]
[35] Fanci, A. S., Morens, D. M.: Zika virus in the Americas-Yet an other arbovirus threat. N. Engl. J. Med., 2016, 374(7), 601604.

[36] Petersen, E. E., Staples, J. E., Meaney-Delman, D., et al.: Interim guidelines for pregnant women during a Zika virus outbreak United States, 2016. MMWR Morb. Mortal. Wkly Rep., 2016, 65(2), 30-33.

[37] Roa, M.: Zika virus outbreak: Reproductive health and rights in Latin America. Lancet, 2016, 387(10021), 843.

[38] Pardi, N., Hogan, M. J., Pelc, R. S., et al.: Zika virus protection by a single low-dose nucleoside-modified mRNA vaccination. Nature, 2017 Feb 2. doi: 10.1038/nature21428. [Epub ahead of print]

[39] Paz-Bailey, G., Rosenberg, E. S., Doyle, K., et al.: Persistence of Zika virus in body fluids - preliminary report. N. Engl. J. Med., 2017 Feb 14. doi: 10.1056/NEJMoal613108. [Epub ahead of print]

[40] European Centre for Disease prevention and Control: Zika virus infection. (Available from: http://ecdc.europa.eu/en/healthtopics/zika_virus_infection/Pages/index.aspx) [accessed: February 18,2017$]$.

(Póka Róbert dr., Debrecen, Nagyerdei krt. 98., 4032 e-mail: pokar@med.unideb.hu)

\title{
MEGHÍV Ó
}

\author{
A Szent János Kórház és Észak-budai Egyesített Kórházak Tudományos Bizottsága \\ tisztelettel meghívja az érdeklődőket a következő tudományos ülésére. \\ Időpont: 2017. április 27. (csütörtök) 14 óra \\ Helyszín: Szent János Kórház Auditóriuma - 1125 Budapest, Diós árok 1-3. \\ Téma: A Szülészet-Nőgyógyászati Osztály eredményei, nehézségei az elmúlt években
}

Üléselnök: Prof. Dr. Jánosi András

\section{Program:}

Végh György dr.: A Szülészet-Nőgyógyászati Osztályon megvalósult álmok, rémálmok az elmúlt 3 évben

10 perc

Zsolnai Csaba dr.: A myomák korszerü kezelése napjainkban

10 perc

Princzkel Erzsébet dr., Flach Edina dr.: Szülészet-Nőgyógyászati és Neonatológiai

Intenzív ellátás korszerü, harmonikus kapcsolata

10 perc

Hernádi Balázs dr.: Modern szemléletủ onkológiai betegellátás - Nőgyógyászati Osztályunk

és az Országos Onkológiai Intézet együttmüködése az elmúlt 2 év összegzése alapján

10 perc

Szécsi Dávid dr.: Prolapsus ambulancia a Szent János Kórházban -

uro-gynecologiai határterület

10 perc

Minden érdeklődőt szeretettel várunk. 